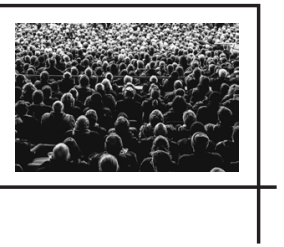

\title{
A CRÍTICA DE CINEMA E OS ÍNDICES DE RECEPÇÃO NA PELÍCULA LA CHINOISE (A CHINESA, 1967), DE JEAN-LUC GODARD
}

\author{
Jailson Dias Carvalho*
}

\begin{abstract}
Resumo: Um dos princípios básicos da estética da recepção assegura que uma obra é o resultado da convergência do texto e de sua recepção, sendo que ela não pode ser apreendida senão em suas "concretizações" (assimilações) históricas sucessivas dos leitores (JAUSS, 1978, p. 246, tradução nossa). De acordo com esse princípio, 0 alcance de uma obra leva em conta o efeito determinado pelo texto e a recepção movimentada pelo destinatário do texto. Dessa forma, o nosso objetivo foi observar qual foi o sentido que a recepção godardiana alcançou ou adquiriu entre cineastas do Cinema Novo e demais críticos cinematográficos, tendo em vista observar quais aspectos da obra La chinoise (1967) foram relevantes para os críticos. Outrossim, a obra filmica do cineasta francês congrega, da mesma forma, indices de recepção (o brinquedo) que permitem ou auxiliam a "entrada" na fita, por parte dos espectadores, ao forjar determinadas pistas ou mecanismos que são comuns entre eles em algumas sequências da fita.
\end{abstract}

Palavras-chave: Recepção. Cinema Novo. La chinoise. Jean-Luc Godard. Brinquedo.

\section{INTRODUÇÃO}

Decorridas cerca de cinco décadas após o seu lançamento em 1967, a película La chinoise, de Jean-Luc Godard, não cessou de produzir efeito junto aos espectadores e admiradores da obra do cineasta francês' ${ }^{1}$ Tal fato chama a atenção para o caráter processual da recepção na

\footnotetext{
* Doutor em História pela Universidade Federal de Uberlândia (UFU). Professor de História na rede estadual de ensino de Uberlândia. E-mail: carvalho_jailson@yahoo.com.br

1 - Nesse tocante, se direcionarmos nosso olhar para o romance Como era triste a chinesa de Godard, do escritor Rodrigo Fonseca (2011), encontraremos algumas balizas que podem esclarecer o caráter que parece nortear a leitura de $A$ chinesa atualmente. Nessa obra, a personagem cinematográfica godardiana sai das telas e ganha um cenário marcado pelo subúrbio carioca de uma casa noturna, intitulada de Bonsucesso Blues; essa foi a opção levada a cabo pelo escritor Rodrigo Fonseca para fazer a ponte entre o cinema e a literatura. Na tentativa de adaptar a personagem de A chinesa para o Rio de Janeiro, Fonseca caracteriza a cidade como permeada pelo cenário do tráfico, pelo universo de consumo de gibis, vídeos e mercadorias e pela distância das utopias de revolução. Nessa eventualidade, de acordo com o personagem principal, "a Internacional perdeu acordes para um disco velho do Roberto que eu comprei em Brás de Pina" (FONSECA, 2011, p. 18). E a chinesa (de Godard, agora do
} 
qual a fita se projetou e esteve imersa, envolvendo distintos públicos e contextos, bem como sinaliza para os aspectos prognósticos e das expectativas e experiências que foram representadas na película.

Nessa eventualidade, a obra filmica do cineasta francês congrega, igualmente, índices de recepção que permitem ou auxiliam a "entrada" na obra. Dessa forma, o emprego dos quadrinhos e do brinquedo, como meio para ilustrar a cena ou a ação proposta, tangencia controvérsias em relação ao deslocamento de instrumentos de um campo para o outro e proporciona uma reflexão sobre o modo como o brinquedo, sobretudo o de guerra, está largamente difundido na atualidade 2 . E neste artigo, notadamente, veremos como o brinquedo é manejado na fita.

Antes de prosseguir, é preciso ter claro que a narrativa da fita trata sobre um grupo de militantes jovens de esquerda que alugam um apartamento durante uma temporada de férias estudantis e, nesse curto período, participam de um grupo de estudos sobre aspectos que envolvem a sua formação tendo como horizonte a revolução. Membros de uma célula marxista-leninista, intitulada Áden-Arábia, alguns desses ativistas lecionam aulas teóricas, e todos praticam exercícios ginásticos. Sua formação prevê a encenação de episódios da atualidade e, como prática, o terrorismo torna-se o meio para se alcançar a revolução.

Nesse sentido, a estética da recepção, tal como defendida por Hans Robert Jauss (2003) em sua aula inaugural na Universidade de Constança, em 1967, fundamentou nossa aproximação sobre a recepção da película de Jean-Luc Godard entre críticos (Paulo Emílio Sales Gomes, Haroldo Marinho Barbosa) e cineastas brasileiros (Carlos Diegues, Glauber Rocha) e a primazia de Glauber Rocha pelo cineasta francês ${ }^{3}$.

Um dos principios básicos da estética da recepção suscita a atenção de Jauss (1978) e interessa-nos: uma obra é o resultado da convergência do texto e de sua recepção, sendo que ela não pode ser apreendida senão em suas "concretizações" (assimilação) históricas sucessivas dos leitores (JAUSS, 1978, p. 246, tradução nossa). De acordo com esse princípio, o alcance de uma obra leva em conta o efeito determinado pelo texto e a recepção movimentada pelo destinatário do texto. Traduzindo para o nosso objeto de reflexão, o filme de Jean-

\footnotetext{
personagem Renato Etecétera, de Rodrigo Fonseca), uma garota de programa que cobrava "R\$ 110 sem anal" (FONSECA, 2011, p. 9), a partir do universo inicial que norteou a personagem Yvonne na fita - uma empregada doméstica que se prostituía -, alimenta os sonhos dele, não de tomada de poder, mas de "dominação global" (FONSECA, 2011, p. 24) pela conquista de uma mulher. Em outros termos, trata-se de um sonho egoísta de um apaixonado, e não um sonho apaixonado de ordem coletiva que outrora alimentou a recepção de $A$ Chinesa entre distintos públicos, sendo que o impacto desse filme em um reduzido grupo de pessoas será abordado neste trabalho.

2 - Assim, mesmo a encenação de esquetes, uma constante referência à pintura imagética da pop art e a incisiva gestualidade dos personagens contribuem para um ingresso na obra filmica La chinoise.

3 - Resguardadas as diferenças entre os suportes físicos, texto literário e a obra filmica de Godard, a estética da recepção atende-nos da seguinte forma: como uma película (um texto) de Jean-Luc Godard foi traduzida (recepção) pelos principais integrantes do Cinema Novo e pelos autores que publicaram matérias sobre A chinesa.
} 
-Luc Godard, sob a forma de texto, produz um determinado efeito nos destinatários (cineastas e críticos) conforme as críticas de cinema nas quais se exprimem.

Dessa forma, trata-se de observar qual foi o sentido que a recepção godardiana alcançou ou adquiriu entre cineastas do Cinema Novo e demais críticos cinematográficos, tendo presente, de acordo com Jauss (1978, p. 248, tradução nossa), que o "sentido se faz por meio de um diálogo, de uma dialética intersubjetiva". Nesse diálogo, há que se levar em conta o caráter comunicativo da obra de arte, que se faz sobre dois planos: o da forma artística e o do sentido. 0 objeto estético adquire uma forma artística e uma resposta. Em outras palavras, trata-se de "esclarecer a evolução da relação entre a obra e o público, entre o efeito da obra e sua recepção, usando a lógica hermenêutica da questão [pergunta] e da resposta" (JAUSS, 1978 , p. 248, tradução nossa).

\section{OS INTEGRANTES DO CINEMA NOVO E GODARD: A RECEPÇÃO DE A CHINESA}

0 lançamento mundial da película A chinesa deu-se em 3 de agosto de 1967, no XXXI Festival de Avignon, e foi exibida em Paris no dia 2 de setembro do mesmo ano (BAECQUE, 2010). No Brasil, o filme foi retido pela censura e somente liberado após o parecer favorável do próprio ministro da Justiça, em 21 de março de 1968 (SIMÕES, 1999)4.

Antecipando-se ao lançamento do filme A chinesa no Brasil e assumindo uma posição de defesa da película ante sua proibição, foi lançado o livro Jean-Luc Godard (1968). De acordo com o editor e organizador Haroldo Marinho Barbosa (1968), os problemas com a censura provocados pelo filme $A$ chinesa foram os motivos da antecipação da publicação. A edição em si é reveladora da condição em que Jean-Luc Godard se ajustava para um conjunto de espectadores e admiradores de sua obra. A imediatez da resposta à censura da película com a publicação sinaliza para uma oportunidade editorial que foi aproveitada.

Nesse sentido, Barbosa revela as razões motivadoras da Coleção Arte do Espetáculo e a escolha de Jean-Luc Godard para inaugurá-la. A obra é direcionada ao espectador médio do cinema e tem por objetivo fornecer um instrumental mínimo que the "possibilite assumir, diante do cinema, uma atitude crítica e participante, e não se limitar a consumir, bestificado, apenas um cinema tradicional" (BARBOSA, 1968, p. 9). 0 pressuposto do editor era de que aquele espectador médio modificasse "sua atitude diante do cinema e da vida" (BARBOSA, 1968, p. 9); assim, o consumo de um cinema revolucionário, no qual o cinema de Jean-Luc Godard se inscreve, não representaria para ele uma dificuldade. Dessa forma, Jean-Luc Godard

4 - A projeção no circuito comercial ocorreu em abril e maio de 1968 no Rio de Janeiro e em São Paulo e, logo após, provavelmente, nas demais cidades brasileiras (O GLOBO, 1968; FOLHA DE S. PAULO, 1968). 
transitaria por um terreno da história do cinema ou da rrte $^{5}$ em que os modos habituais de leitura de um filme tradicional não permitiriam uma maior compreensão ou seu entendimento (BARBOSA, 1968).

Termos como "revolucionário" e "cineasta polêmico" foram usados para qualificar Jean-Luc Godard6. Estes, por um lado, garantiriam a inserção da obra no mercado editorial, condição reconhecida pelo editor como oportuna "para uma maior penetração do livro" (BARBOSA, 1968, p. 10); por outro lado, a incompreensão que recaía sobre o cineasta francês justificaria uma seleção de entrevistas, ensaios e diálogos do filme $A$ chinesa, conforme considera Barbosa (1968).

Os adjetivos atribuidos a Godard e a constatação da condição de incompreendido que recobriu sua obra já eram um indicativo da recepção godardiana pelo editor. Essa recepção é análoga à primazia glauberiana por Godard, no sentido de defender o cineasta de Acossado em face das críticas à direita e à esquerda do espectro político cinematográfico ${ }^{7}$, bem como de enxergá-lo como "um dos dois ou três mais importantes autores de cinema" da atualidade (BARBOSA, 1968, p. 10). Por outro lado, na trilha defendida por Glauber Rocha (1967), observa-se, na publicação, um desejo de alargar o valor cultural do cinema como uma arte de relativa importância ${ }^{8}$.

Assinaladas as linhas gerais da publicação que acompanhou o lançamento do filme $A$ chinesa no Brasil, cumpre destacar que a contracapa de apresentação dessa obra esteve a cargo do cinemanovista Carlos Diegues. A importância de Godard para a formação cinema-

5 - 0 trânsito de Jean-Luc Godard pelo terreno da história da arte decorre do fato de que a coleção previa a tradução de Arnold Hausser, o que patentearia um lugar para ele naquela história.

6 - Esses adjetivos usados para se referir à película $A$ chinesa estavam bastante difundidos, e não escaparam do alcance estabelecido pela publicidade que foi utilizada para divulgar o filme nos jornais diários. Veja, por exemplo, a Figura 1. 0 modelo de propaganda do filme, ali referido, assinala, por sua vez, os aspectos que foram privilegiados com o objetivo de cativar o espectador para o cinema: seja a novidade que a fita representava, ou a utilização do adjetivo revolucionário, termo que sinalizava para as lutas politicas da época.

7 - É preciso enfatizar que não havia unanimidade em relação a Godard no Brasil. 0 jovem cineasta brasileiro Glauber Rocha escreveu um artigo em 1967, tendo em vista se colocar como mediador em relação ao diretor francês, buscando retirar ou minimizar as arestas que impediam uma maior compreensão de sua obra fílmica.

8 - A conexão do cinema com a literatura e a pintura e a valorização do cinema como uma arte de não menos estima que as demais ocupam um relativo espaço no artigo glauberiano. Nesse sentido, o tema Jean-Luc Godard permitiu a Glauber Rocha aquilatar a história do cinema, agregando-o às belas-artes; dessa forma, Eisenstein "chegou ao esplendor de um cinema renascentista", Orson Welles "deu a grande festa de despedida do expressionismo", Rossellini inaugurou o "cinema moderno" e Godard é o "seu filho direto e legítimo", "o herdeiro do novo cinema é Jean-Luc Godard", assegurou Glauber Rocha (1967, p. 88-90, grifo do autor). Depreende-se desse artigo de Glauber a seguinte proposição: coube a ele examinar a obra de Godard em face das críticas que lhe eram destinadas pelos segmentos mais à esquerda e à direita do espectro político e cinematográfico brasileiro e, ainda, como já notado, alargar o valor cultural não somente do cinema nacional junto à intelectualidade, mas do fazer cinema e do pensar sobre o cinema também (AUTRAN, 2003, p. 245). A ampliação do valor cultural do cinema faria parte de uma luta político-cinematográfica na qual estava envolvida uma parte expressiva de cineastas, críticos de cinema e intelectuais e que não parece ter sido equacionada na metade dos anos 1960. 
tográfica dos jovens é descrita com arrebatamento por ele. Contudo, chama a atenção o conceito de "cineasta Tricontinental" atribuído a Godard por Cacá Diegues, que se relaciona diretamente com a política:

Godard é o pintor dos marginais de um mundo moderno em que o grande marginalismo é a ação política contra o poder. Nem anarquista de direita, nem individualista cínico, mas um atormentado filho de Descartes com a Bêsta, tentando pôr em ordem a desordem ocidental, cineasta Tricontinental no seio do Primeiro Mundo (DIEGUES, 1968).

Diegues procurou capitanear o lançamento de A chinesa para a luta política imediata dos cineastas brasileiros, como o enfrentamento contra o modelo cinematográfico representado por Hollywood, a censura e o regime militar, divisando, no cineasta francês, uma figura que não se enquadrava num único continente ou que, dentro das fronteiras europeias, procurava dinamitar as estruturas do imperialismo ocidental do cinema.

Podemos constatar também, no texto de Cacá Diegues, uma inflexão significativa em seu pensamento. Para os aspirantes do Cinema Novo que militavam no jornal O Metropolitano no final da década de 1950, entre os quais estava Cacá Diegues, o caráter falho da Nouvelle Vague, não é por demais lembrar, decorria do fato de ela não justapor à pesquisa formal o envolvimento com a política. Noção diversa transitava entre os integrantes do Cinema Novo no final da década de 1960. Jean-Luc Godard descobriu a política, constatou Cacá Diegues (1968): "Mais uma vez, Godard, ele mesmo: é deplorável que quem tem cultura cinematográfica não tenha cultura política, e vice-versa. 0 cinema político será, assim, ainda durante muito tempo um ofício de catacumbas".

A posição de Diegues provavelmente se relaciona ainda com o pensamento de Ernesto Che Guevara. É necessário referir a Mensaje a los pueblos del mundo a través de la Tricontinental, escrita pelo dirigente revolucionário cubano, que sinalizava, entre outras situações, para um internacionalismo proletário no qual seria bem-vindo o surgimento de um front de batalha, exemplificado pelo florescimento de dois, três Vietnãs "na superfície do globo, com sua quota de morte e suas tragédias imensas, com seu heroísmo quotidiano, com seus golpes repetidos ao imperialismo", obrigando-o a "dispersar suas forças" (GUEVARA, 2003).

No desejo de Carlos Diegues, Jean-Luc Godard se transmutava em aliado de um conjunto de cineastas e de determinadas frentes culturais brasileiras. Sua posição, provavelmente, filia-se à perspectiva de cinema tricontinental defendida e formulada por Glauber Rocha, segundo a qual, de acordo com Mauricio Cardoso (2007, p. 14-15), representava um

[...] projeto cinematográfico capaz de efetivamente romper com os limites da nacionalidade, integrando as experiências políticas e estéticas dos paises pobres. Ele [Glauber Rocha] esta- 
beleceu as bases deste programa que, embora não chegasse a ser efetivado, conseguiu esboçar o que estaria em jogo. Inspirado numa perspectiva que definiu como "cinema tricontinental", Glauber pretendeu liderar uma revolução cultural que tomaria de assalto o campo cinematográfico mundial. Originária da conferência de Havana, em 1966 e, particularmente, na intervenção de Che Guevara, a perspectiva de uma unidade política dos três continentes (América Latina, África e Ásia) para combater o imperialismo, a Tricontinental transformava-se na prática de Glauber num instrumento de convergência das diversas cinematografias nacionais. Aos temas da luta política e econômica, ele associava a necessidade de uma luta cultural (estética, inclusive) como condição para a liberdade dos povos subdesenvolvidos. Este programa ousado, comovente e, em certo sentido, delirante representou uma alternativa aos impasses do subdesenvolvimento, na medida em que sistematizou uma pauta objetiva de ação no campo cinematográfico, desenhou as linhas gerais de uma nova estética e realizou filmes que sugeriam alguns caminhos possíveis. Além disso, o Cinema Tricontinental garantiu, mesmo que por um curto periodo, um patamar de debate com a crítica europeia que, efetivamente, transformou a representação dos intelectuais brasileiros em interlocutores dotados de cultura própria.

De certa forma, as posições políticas encetadas por Jean-Luc Godard no contexto do cinema europeu, em face da expansão agressiva do imperialismo norte-americano no mundo, e a crítica dele ao envelhecimento que atingia a sociedade de consumo, conforme afirma Román Gubern (1974), condição que transparece em algumas de suas obras cinematográficas e entrevistas, facultam uma maior aproximação dos cineastas brasileiros em relação a Godard e ao pensamento de Che Guevara.

De certa forma, a aproximação de Cacá Diegues de Jean-Luc Godard foi entremeada por uma simpatia por Che Guevara, visto que o eco de adesão ao dirigente cubano transparece no discurso de apresentação de $A$ chinesa (comentado adiante). Ou seja, o fato de o líder cubano ser a ponte entre os dois facultou uma identificação, um interesse e mesmo uma esperança em relação ao maoísmo, pois estavam presentes no foquismo, representado por Che Guevara, ideias do maoísmo, como, por exemplo, a guerra popular de apoio ao campesinato e uma abordagem voluntarista da revolução.

Não é por demais lembrar que, para os maoístas franceses, o caminho que levava até a China incluía Havana no percurso, e Godard e Diegues, possivelmente, compartilharam do mesmo trajeto de esperança que eles. A chinesa, evidentemente, cimentou o caminho, pois implícito está na fita que Jean-Luc Godard reconhece o maoísmo como um ator importante e uma referência para a esquerda e para o enfrentamento do imperialismo cinematográfico americano no mundo.

Em entrevista concedida à revista Cahiers du Cinéma, em outubro de 1967, a proposta defendida por Guevara do florescimento de um front de batalha no mundo, tendo como 
exemplo a guerra do Vietnã contra os norte-americanos, manifesta-se na publicação de propaganda que acompanhou o pressbook de A chinesa:

Cinquenta anos após a Revolução de Outubro, o cinema americano reina sobre o cinema mundial. Não existe grande coisa a acrescentar a esse estado de fato. Exceto que em nosso universo, nós devemos também criar dois ou três Vietnam no seio do imenso império Hollywood-Cinecittà-Mosfilms-Pinewood, etc. - tanto economicamente quanto esteticamente, quer dizer lutando em dois fronts, criando os cinemas nacionais, livres, irmãos, camaradas e amigos (GODARD, 1991, p. 9).

A postura de Cacá Diegues, tanto quanto a de Glauber Rocha naquele período, entre os anos de 1967 e 1968, e porventura também em 1969, aproximar-se-ia das posições de Jean-Luc Godard, sobretudo no que diz respeito ao incremento de um outro modelo de cinema, contraposto ao de Hollywood na época.

De acordo com Antoine de Baecque (2010), em fevereiro de 1967, Jean-Luc Godard foi convidado, pela cinemateca da cidade de Argel, na Argélia, para uma retrospectiva de seus filmes junto a estudantes e demais presentes. Na eventualidade, ele fez um discurso muito próximo daquele que propunha Glauber Rocha ${ }^{9}$, sobretudo em torno de um cinema alternativo ao modelo de Hollywood e que não renunciasse à poesia nem à política (BAECQUE, 2010).

A difícil equação que configurava a junção desses termos numa película, ou mesmo a contraposição ao modelo hollywoodiano, parece estar inscrita na metáfora criada por Cacá Diegues, segundo a qual "o cinema político será [...] durante muito tempo um ofício de catacumbas" (DIEGUES, 1968). Provavelmente, tal metáfora fosse o indicativo das possibilidades, do alcance e dos impasses do cinema político entre os anos finais da década de 1960, prognosticando um esgotamento daquele gênero cinematográfico e seu isolamento por parte do grande público, que preferiria o filme tradicional, ou pela censura, como foi o caso brasileiro.

No entanto, a proximidade de posições que Glauber Rocha parece manter com Jean-Luc Godard torna-se clara nos comentários que ele tece a respeito de A chinesa em suas cartas. Nelas, constatou unicamente que a fita "será o manifesto maoista de Godard" (BENTES, 1997, p. 281). Se, publicamente, Glauber Rocha não aderiu politicamente ao maoísmo ${ }^{10}$, em determinados textos não se mostrou intransigente em relação a ele:

9 - Cabe destacar que a obra godardiana inscreve-se, para Glauber, num horizonte de expectativas que não pode ser menosprezado: "Godard planta o futuro cinema popular, industrial, colorido, internacional, que será transmitido de satélites espaciais pelas cadeias de TV do Figaro-Pravda-New York Times-China Press" (ROCHA, 1967, p. 93).

10 - Nessa eventualidade, nota-se que não somente as questões estéticas nortearam as preocupações de Glauber Rocha, seja em relação a seus filmes, seja em relação à politica cinematográfica; sua relação com a sociedade brasileira foi permeada por 
A grande contribuição de Mao é derrubar esta ditadura [sobre o proletariado] por uma verdadeira democracia proletária. Democracia operária - ou seja, democracia entre os que produzem é o justo, e através deste princípio democrático, podemos entender democracia como dialética (ROCHA, 1981, p. 136).

A estreita simpatia em relação ao tema da democracia proletária na China presente em Glauber Rocha, possivelmente em decorrência da deflagração da Revolução Cultural Proletária"1 , evidencia um traço da recepção daquele movimento chinês pelo cineasta brasileiro, em consonância, todavia, com os militantes pró-maoístas franceses no mesmo período (finais dos anos 1960). Cabe frisar que também eles observavam a China como a "terra da eleição da democracia direta" (MARNIX, 2009, p. 20), sem, contudo, medirem a prática autoritária do regime.

Contudo, seria na obra Revolução do cinema novo que se notariam maiores impressões de Glauber sobre A chinesa. Antes de prosseguir, cabe frisar que também Paulo Emilio Salles Gomes se pronunciou sobre A chinesa, e o fato de ter produzido duas críticas dá-nos a relevância que a película alcançou para ele.

Paulo Emílio Salles Gomes escreveu semanalmente, por quatro anos, para o "Suplemento Literário" do jornal O Estado de São Paulo e foi considerado uma figura de referência cultural e política para os jovens cineastas do Cinema Novo. Além de ter escrito diversos artigos sobre distintos assuntos nos principais jornais do país, manteve correspondência pessoal com Glauber Rocha e outros integrantes daquele movimento cinematográfico brasileiro.

\footnotetext{
uma busca pela intervenção política. Cabe delinear a participação efetiva de Glauber no financiamento direto à agremiação Aliança de Libertação Nacional (ALN), mediante a coleta de recursos junto a cineastas (Jean-Luc Godard e Gianni Amico, por exemplo) (PAIVA, 1996). Na oportunidade, Mário Magalhães (2012) assinala, na biografia sobre Marighella, que Godard, além de dar apoio financeiro à ALN, pretendia ainda fazer um filme sobre os 15 prisioneiros políticos libertados com o sequestro do embaixador americano Charles Burke Elbrick em 1969, mas Glauber Rocha pediu a Godard que desistisse da ideia, pois havia o temor de que a situação pudesse se agravar ainda mais.

11 - Os marcos cronológicos da Revolução Cultural Proletária Chinesa são controversos. De acordo com Camille Boullenois (2013), os historiadores chineses consideram que seu período de abrangência compreende dez anos (1966-1976), mas determinados historiadores ocidentais, como Marie-Claire Bergère, recusam essa periodização, assinalando que seria preciso atentar para várias considerações políticas que nortearam a Revolução Cultural Proletária (BOULLENOIS, 2013). Yves Chevrier (1996, p. 130-131), por sua vez, evidencia que "a decisão de lançar uma 'revolução cultural' é tomada em 1964. 0 aparelho do partido [comunista chinês] a aprova apenas segundo sua própria perspectiva, obstruindo as iniciativas do presidente: pois Mao só avança ficando imóvel. Suas diretrizes não são mais aplicadas... quando ele é consultado". Contudo, Chevrier (1996, p. 114) considera os anos de 1966-1968 como de vigência da Revolução Cultural, classificada por ele como um "fenômeno basicamente urbano".
} 
Figura 1 Propaganda de lançamento do filme $A$ chinesa em São Paulo



Fonte: Folha de S. Paulo (1968, p. 3)

A tônica que recobre a primeira crítica sobre o filme, escrita por Gomes (1986a), procura pôr em contraposição a tolice e A chinesa. No polo da tolice está, em primeiro plano, a censura brasileira ao filme, um dos motivos que permitiu a edição da obra Jean-Luc Godard em tempo hábil por Haroldo Marinho Barbosa (1968) ${ }^{12}$.

Ao opor tolice vs. A chinesa, Gomes (1986a) procura enfatizar que a fita se colocava no plano dos filmes inteligentes, que, juntamente às fitas brasileiras de mesmo nível, padecia com a censura. A defesa da fita, portanto, veio ao encontro de um anseio de segmentos culturais brasileiros insatisfeitos com as constantes intervenções da censura em seus filmes, peças, coberturas jornalísticas, no movimento estudantil, entre outros, que sofriam nas mãos de censores e interventores.

Entretanto, a estratégia da justificativa de Gomes para liberação da fita aos espectadores brasileiros adveio da ênfase que ele atribuiu ao fato de que a fita não foi aplaudida por nenhum grupo político na França, fosse do espectro político à esquerda, fosse à direita. Em compensação, o crítico admitia que a fita "suscitou muito pensamento e reflexão em indivíduos pertencentes a qualquer dessas tendências ou mesmo aos partidos políticos que delas emanam" (GOMES, 1986a, p. 249).

\footnotetext{
12 - A pequena crônica do autor, publicada no final de abril de 1968 e antes do lançamento de A chinesa em São Paulo, é pontuada de ironia contra o que ele nomeia de "acumulação primitiva de tolice na vida social brasileira" (GOMES, 1986a, p. 248), aludindo à "burrice censorial", que é "fascinada" pela "produção estrangeira, tola", e "compreensiva" em "relação aos filmes brasileiros tolos". Nesse ponto, em sua opinião, os censores agiam acertadamente, pois "a tolice é nossa" (GOMES, 1986a, p. 248-249).
} 
Contudo, o maior absurdo que poderia ser observado na censura ao filme, de acordo com o autor, era a tentativa de descobrir qualquer tipo de propaganda em A chinesa, pois a fita buscava "se comunicar com a inteligência individual de cada espectador, tomado isoladamente" (GOMES, 1986a, p. 249). Embora esse não fosse o menor dos méritos da fita para o autor, sua definição do que era $A$ chinesa torna-se relevante sobre as problemáticas que 0 sensibilizaram na obra: "é um filme que estuda simplesmente as perplexidades ideológicas e vitais de um setor da juventude de uma grande cidade do ocidente, gravando as intermináveis discussões a respeito dos comunismos" (GOMES, 1986a, p. 249).

Se o tema da primeira crítica do ensaísta foi a censura e a tolice que imperavam na vida social brasileira, o destaque da segunda crônica sobre a fita, publicada em princípios de junho de 1968, compreendia a tentativa de explicar o que era a película de fato para o público que assistiu a ela e teve dificuldades de entendê-la. Uma indagação impõe-se: se, para o autor, o "filme estuda simplesmente as perplexidades ideológicas e vitais de um setor da juventude de uma grande cidade do ocidente" (GOMES, 1986a, p. 249), por que se deu o trabalho de tentar explicá-lo?

Gomes, em sua crítica, diferentemente da postura engajada de outros integrantes do Cinema Novo, procurou, enxergou e/ou preferiu notar na fita aspectos que dizem respeito à fatura interna dela, como sua estreita vinculação com o teatro e a política (sobretudo, o Maio de 1968 francês) e seu traço documental mediado pela entrevista, aspecto que envolve os personagens à medida que são interpelados sobre suas trajetórias (GOMES, 1986b). Vejamos a construção de seu argumento.

Ele estabelece três condições necessárias para qualquer pessoa gostar de A chinesa. A primeira refere-se ao fato de que é preciso gostar de conversa, pois a obra filia-se a um gênero de filmes baseados em entrevistas. Independentemente de o filme basear-se na espontaneidade documental ou ficcional, esse gênero de fala é o oposto do diálogo habitual. 0 ensaista compara a forma dos diálogos encontrados na película com as "múltiplas experiências do cotidiano: as linhas telefônicas cruzadas, as conversas ouvidas nas filas, nos ônibus, nos cafés e balcões" (GOMES, 1986b, p. 254-255). Essas múltiplas experiências do cotidiano já nos garantiriam uma vantagem em sermos "espectadores de conversa" que a fita proporciona (GOMES, 1986b, p. 254-255). 
Figura 2 Propaganda de lançamento do filme A chinesa no Rio de Janeiro

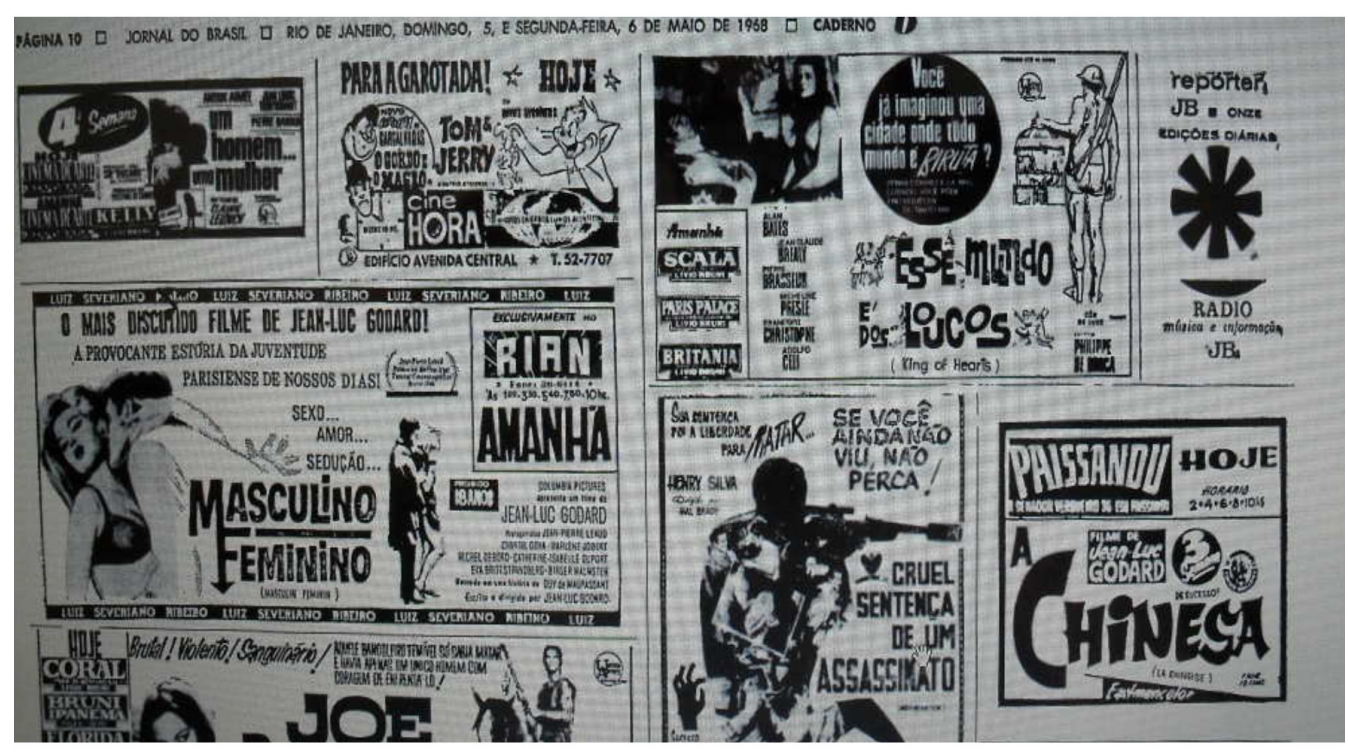

Fonte: Jornal do Brasil (1968, p. 10) ${ }^{13}$.

Gomes (1986b, p. 255) procura relacionar a experiência que o público tem com o teatro - o "teatro não pretende mais enganar ninguém; [...] é do desengano que procura nos atingir" - e a trajetória do teatro na película. Enfatiza que o diretor deu um especial interesse ao destino de Guilhaume, o ator, o personagem mais próximo do teatro. Considera, ainda, que as "passagens dramaticamente mais eficazes", como a sequência do Vietnã, decorrem da "profunda sacudidela sofrida pelo teatro" (GOMES, 1986b, p. 255). Ele finaliza essa reflexão sinalizando para o jogo, a brincadeira, na fita; pelo fato de "ser tão infantilmente 'de mentira' é que nos atinge tanto o lamento de Yvonne: 'Socorro, Senhor Kosseguine, socorro..." (GOMES, 1986b, p. 255) $)^{14}$.

Por fim, para gostar do filme, era preciso gostar de política. 0 crítico procurou, a exemplo da conversa e do teatro, notar que, também sobre esse assunto, sobravam exemplos que poderiam preparar excessivamente o espectador para o universo do filme, levando em conta

\footnotetext{
13 - 0 lançamento da película no Rio de Janeiro foi simultâneo à estreia de Masculino, feminino. No Rio de Janeiro, A chinesa ficou mais de cinco semanas em cartaz e foi proibida para menores de 18 anos, estratégia da censura para impedir que os adolescentes assistissem à obra de Jean-Luc Godard. A classificação etária para o filme A chinesa, editado em DVD pela Silver Screen Collection, foi considerada livre, conforme a Portaria n 1.597, de 2 de julho de 2004.

14 - Trata-se de uma sequência que compreende o enquadramento de Yvonne no centro da cena. Ela traja uma roupa típica de uma vietnamita: uma tigela numa das mãos, um par de hashi na outra e um chapéu típico de uma camponesa na cabeça. Ao fundo, um enorme tigre pintado e dois aviões de brinquedo de guerra americanos transitam a seu lado; logo após, investem contra ela, que pede socorro. Ver parte da cena na Figura 3, a seguir.
} 
o noticiário a respeito da França naquele período" ${ }^{15}$. Contudo, ele ressalva que o filme "tornou-se tão atual que o público se inclina a levar um pouco a sério demais, como revolucionários, aqueles jovens que tanto falaram e ocasionalmente mataram ou se mataram" (GOMES, 1986b, p. 255). Se considerarmos o aspecto de balanço de experiência que esteve presente na trajetória de Véronique, que reavaliou suas ações na película, a constatação e o comentário de Gomes indicam traços da recepção pelo público do filme no Brasil, que assumiu como real o percurso dos personagens ${ }^{16}$.

Assinalada a contribuição de Gomes, podemos retomar as considerações de Glauber Rocha. Primeiramente, uma constatação de ordem genérica: "La chinoise é um filme dialético" (ROCHA, 1981, p. 136). Ou, em outros termos, para ele, poderia ser considerado um filme dialético toda película que detivesse um rigor na conjunção entre "informação, imaginação, razão e coragem, elementos sem os quais qualquer obra de arte não se realiza" (ROCHA, 1981, p. 117).

0 termo "dialético", que Glauber Rocha atribui à película, é revelador do efeito que ela produziu no cineasta. Antes de prosseguir, cabe ressaltar que nos baseamos aqui nas reflexões de Michael Baxandall (2006) para analisar o efeito provocado pela fita no diretor brasileiro, condição que também pode ser estendida aos demais críticos e autores que escreveram sobre A chinesa.

Os três modos indiretos de nossa linguagem - que correspondem a três maneiras de pensar um quadro figurativo, propostas por Michael Baxandall (2006) em uma obra que trata sobre a explicação histórica dos quadros - tornam-se válidos para entendermos a postura de Glauber Rocha em face da fita. Resguardadas as distintas notações entre filme e quadro e substituindo o termo objeto por filme, suas considerações, grosso modo, resumem-se em: "falar diretamente do efeito que o objeto [filme] provoca em nós, estabelecer comparações com coisas que produzem um efeito semelhante, fazer inferências sobre o processo que teria levado um objeto a nos causar efeito" (BAXANDALL, 2006, p. 38) ${ }^{17}$.

Portanto, identificados os modos indiretos da linguagem, cabe-nos retomar Glauber Rocha, que, ao afirmar "La chinoise é um filme dialético", está nomeando, conforme já assi-

\footnotetext{
15 - Ele se refere aos confrontos entre estudantes e as forças policiais durante o movimento que ficou conhecido como Maio de 1968 francês.

16 - Em suma, as balizas que nortearam a crítica de Paulo Emílio e promoveram o melhor entendimento da película pelo espectador tiveram como ponto de partida, conforme já denotado, as múltiplas experiências do espectador, como os diálogos de que participa ou que entrevê, a experiência do teatro de cada um e o pressuposto de que o espectador não esteve alheio à política ou às notícias que relatavam os acontecimentos ocorridos na França em maio de 1968. Paulo Emílio parte do espectador como denominador para o entendimento dos temas da película.

17 - Pressuposto está, para Michael Baxandall (2006), que nos valemos da descrição verbal para explicar um quadro, sendo que toda descrição delineia o que pensamos sobre esse quadro. As palavras que possibilitam tais descrições são instrumentos de generalização e "permitem inferir causas, caracterizar efeitos, fazer diversas comparações" (BAXANDALL, 2006, p. 43).
} 
nalado, o efeito que o filme produziu nele. Sua definição de dialética corrobora a afirmação de Michael Baxandall (2006), pois procura comparar termos que produzem nele o mesmo sentido que a noção de dialética defendida por ele (por exemplo, um soneto de Petrarca), estabelecendo inferências sobre as causas que possibilitaram o termo dialética infundir determinado efeito sobre ele (a lógica, a sensação e a percepção que estão presentes tanto no soneto quanto em Godard):

A dialética me parece um soneto - em Petrarca, por exemplo, há tanta lógica quanto há tanto imponderável sensação e percepção; são funções básicas do poema. De Petrarca a Mallarmé - seria como de Chaplin a Godard - neste momento a obra de arte se faz prática e (práxis) no cinema nada mais fascinante (ROCHA, 1981, p. 136).

A constatação de Glauber Rocha sobre Jean-Luc Godard possibilita discernir que o cineasta de Câmera-olho assumiu para ele uma representação que pode ser avaliada com base na noção de angústia da influência, formulada por Harold Bloom (2002). Entretanto, tal assunto ultrapassa os limites a que nos permitimos neste artigo, e trataremos na próxima seção sobre a problemática do brinquedo na película La chinoise.

\section{O BRINQUEDO EM A CHINESA}

0 uso do brinquedo em $A$ chinesa apresenta vários aspectos. Ele serviu de apoio à narrativa, tendo o intento de estabelecer a crítica contra aqueles que interferem na "causa justa" da guerra ou são um obstáculo ao "progresso"18. E o maior inimigo nesse processo são os

18 - Chama nossa atenção o movimento que transparece na narrativa filmica mediante a ação dos personagens da célula revolucionária Áden-Arábia, que impele rumo a um determinado progresso, valendo-se, como meio, da justificativa da guerra. Guerra, terrorismo e revolução parecem ser sinônimos para uma condição que se deseja alcançar: a mudança das velhas ideias, velhas culturas, dos velhos hábitos e velhos costumes, tal como pode ser entrevisto na lousa que se encontra na sala de aula improvisada do apartamento alugado. 0 progresso torna-se o horizonte comum de uma busca que se justifica até mesmo com o suicídio do personagem Kirilov, que assume, com a perda de sua vida, ser o verdadeiro culpado pelo atentado ao ministro da Cultura soviético. Nesse prisma, o grupo de estudos revolucionários vale-se de todos os meios para absorver, compreender e acelerar o processo que deve conduzi-lo a seu objetivo. A cena que sinaliza para esse movimento rumo ao progresso é pontuada por Guillaume, que discorre sobre Problemas de informação/Por uma TV republicana, e cabe delineá-la. Tal personagem representa, na fita, um jovem cujo pai teria trabalhado com Antonin Artaud. Durante sua preleção sobre as atualidades, e desobrigando-se somente das questões teóricas sobre a conjuntura política mundial, propõe aos demais camaradas da célula um exercicio prático: discursar acerca da informação em seus diferentes aspectos, notadamente sobre a guerra do Vietnã. Após a exposição, que requer uma resposta dos ouvintes, a sequência apresenta Guillaume sentado, e notamos, mais uma vez, a maneira como conduz a atividade: nesse caso, o personagem pretende que os demais proponham o tema que servirá de exemplo para ilustrar a "teoria" supostamente aprendida. Sobre a mesa, estão dispostos vários óculos de sol. Ao fundo, na lousa, está uma página do jornal Garde Rouge. Guillaume está com um cigarro entre os dedos. Ele afirma que, numa informação, é preciso 
norte-americanos, haja vista a bandeira desse país no porta-aviões, no tanque de guerra e nos aviões de combate que atacam a personagem Yvonne na cena seguinte, que será analisada mais adiante.

A narrativa de A chinesa não poderia prescindir, grosso modo, de uma retórica de guerra, pois a fita reporta-se ao léxico do maoísmo, que não se contrapõe ao uso da guerra. Ao contrário, ele faz da guerra seu instrumento. Mao Zedong (2004, p. 53) afirmava que "a guerra é a continuação da política".

Portanto, não somente o brinquedo de guerra presente na película $A$ chinesa retorna à atmosfera comunista mais geral e, especificamente, maoísta, mas também uma série de gravuras e imagens recorrem a esse universo, tais como a mão que segura um fuzil ou uma câmera que emite o som de uma metralhadora e, depois, torna-se um fuzil nas mãos da personagem Véronique. Assim, o voluntarismo ou a predisposição para o combate tornam-se um veio possivel, em que parece transitar o universo da película no papel de determinados personagens.

0 brinquedo permite também estabelecer um índice de recepção ou de ingresso na obra de arte $A$ chinesa por parte dos espectadores, ao forjar determinadas pistas ou mecanismos que são comuns entre eles em algumas sequências da fita. Temos presente um princípio da

analisar o problema em seus diferentes aspectos, e olha para os integrantes da sala quase sorrindo: "Chega de teoria. Vamos a um problema prático!" (LA CHINOISE, 1967). Propõe que os demais participantes decidam o tema e apenas a voz deles se destaca na cena: Véronique sugere a guerra; Henri sugere a região da Ásia; Guillaume propõe então o Vietnã como exemplo. E o Vietnã torna-se o tema escolhido, sendo que, valendo-se de um esquete sobre a guerra que faz recordar um jogral estudantil, os personagens Guillaume e Yvonne declamam frases pontuadas por brinquedos. Os personagens declamam pausadamente as palavras, enquanto um porta-aviões de brinquedo investe jatos e artilharia pesada contra um alvo aparentemente desconhecido, mas que, no decorrer da narrativa cinematográfica, torna-se claro. Cada personagem surge na tela individualmente, um após o outro. A mensagem que transmitem procura vincular os termos guerra, progresso e comunismo. A guerra (ou seria revolução?) é necessária e trará o progresso. A animação do porta-aviões, de bandeira estadunidense, sugere uma ação em andamento; contudo, a declamação do jogral indica uma concordância com o princípio da guerra, pois o discurso é entrecortado com imagens de aviões e artilharia e pontuado pela fala dos personagens olhando para a câmera. A ação de um conflito, nas palavras deles, é progressista e justa. Contudo, a ação de um conflito que obstrui o progresso é injusta. Nesse instante, a narrativa filmica assume uma posição contra aqueles que constituem um entrave ao progresso, e o porta-aviões aparece na tela. 0 próximo conjunto de frases leva adiante esse posicionamento, delineando os atores que trarão o progresso: os comunistas e, em especial, o comunismo chinês, pois, na imagem seguinte, surge uma fotografia de um grupo considerável de jovens chineses empunhando O livro vermelho, com os conteúdos políticos de Mao Zedong. Os atores declamam, pausadamente, interpondo a fala de um com a do outro: "nós comunistas, lutamos contra todas as guerras que travam o progresso" (LA CHINOISE, 1967). Surge então a imagem de um tanque de brinquedo em movimento com a bandeira estadunidense e a música-tema dos filmes de cavalaria. À medida que os atores e o tanque se alternam na fita, os personagens declamam o verso final, que sintetiza a cena em questão: "mas não somos contra as guerras progressistas", e arremessam vários exemplares de O livro vermelho no tanque de brinquedo, que não consegue prosseguir em seu trajeto. 0 movimento em direção ao progresso imanente à narrativa fílmica de $A$ chinesa sinaliza para aspectos em que a tensão entre o velho e o novo e o passado e o futuro entram em choque na fita. Nessa direção, a problemática da guerra ou a justificativa para uma ação bélica denota esse estado, pois a revolução, como um processo intermediado pela aceleração, pela mudança permanente, nas palavras de Koselleck (2006), e pela condição de irreversibilidade, impele a ação dos personagens a um conflito em que o terrorismo se torna o meio mais adequado para se alcançar o progresso. 
teoria da recepção manejado por Hans Robert Jauss (2003) para entender o sistema de referências que compõe o horizonte de expectativas do público da obra de arte literária, que não parece distante daquele que experimenta pela primeira vez a obra fílmica.

De acordo com o autor, uma obra de arte, no momento de seu surgimento, não se apresenta nunca como uma novidade para o público, "como num vácuo de informação" (JAUSS, 2003, p. 66); ao contrário, ela predispõe o "público para uma forma bem determinada de recepção, [ao facultar a ele] informações, sinais mais ou menos manifestos, indícios familiares ou referências implícitas" (JAUSS, 2003, p. 66). Nesse sentido, o processo de percepção do público é orientado e pode ver frustradas suas expectativas, uma vez que se entrelaça com os fios do enredo da composição artística:

[A obra] evoca obras já lidas, coloca o leitor numa determinada situação emocional, cria, logo de início, expectativas a respeito do "meio e do fim" da obra que, com o decorrer da leitura, podem ser conservadas ou alteradas, reorientadas ou ainda ironicamente desrespeitadas, segundo determinadas regras de jogo relativamente ao gênero ou ao tipo de texto (JAUSS, 2003, p. 67).

Se substituirmos a referência ao leitor de uma obra literária, apresentada nas expressões de Jauss (2003), pela referência ao espectador do cinema, teremos que admitir que, no primeiro contato dele com a sequência da fita $A$ chinesa, que trata sobre os brinquedos de guerra, há, de antemão, uma reorientação para um protesto do cineasta contra o imperialismo norte-americano. Nesse sentido, o brinquedo, destituido do contexto marcado pela brincadeira, permitiu a crítica à técnica de guerra e a seus armamentos bélicos, tais como aviões de combate, tanques e o poderio naval de porta-aviões estadunidenses.

\section{A pop art em $A$ chinesa e a nose art}

Podemos atribuir, à imagética da pop art, o mesmo princípio da estética da recepção no que diz respeito às pistas, aos mecanismos que são comuns a determinados espectadores que tomam contato com a fita, e percebemos um deslocamento de seu sentido na narrativa. Procedimentos de colagens de fotos e jornais, assim como o uso de personagens das histórias em quadrinhos (Batman, Super-Homem, Sargento Fury, Capitão América) - traços da estética pop -, são constantes na fita.

Jean-Luc Godard, em A chinesa, aplica a técnica do objeto achado da pop art nas diversas imagens de histórias em quadrinhos de que faz uso na película e procura, assim, intensificar a ação dramática na qual os personagens estão envolvidos. A partir da obra de um artista da pop art, ele busca, ao mesmo tempo que faz alusão a esse movimento artístico, justapor à ação narrativa um esquete para defender a Frente de Libertação Nacional (FLN) do Vietnã. 
A cena na qual esses elementos estão conjugados é uma continuação da sequência em que o personagem Guilhaume, conforme assinalado, protagoniza uma conferência sobre Os desafios de uma TV republicana. Após os integrantes da célula terem escolhido, como tema para o exercício prático, a guerra do Vietnã, o personagem, impregnado de gestos dos profissionais da educação, divisa seu olhar para o espectador e, juntando o polegar com o dedo médio, produz um som, permitindo ao espectador associá-lo ao diretor de um filme, cuja ação será mostrada em seguida. Tal demonstração denota outro espaço cinematográfico no qual a fita se abre.

A sequência é bastante curta e tem por objetivo apresentar uma situação que, posteriormente, será retomada pela personagem. Yvonne está no centro da cena e veste uma roupa típica de uma vietnamita: com uma tigela numa das mãos, um par de hashi na outra e um chapeu típico de uma camponesa. Ao fundo, um enorme tigre pintado e dois aviões de brinquedo com a cor dos aviões de guerra americanos transitam ao seu lado.

Yvonne dissimula comer algo. Percebe-se sua encenação. Os dois aviões aproximam-se dela: um vem pelo alto, e o outro quase derruba seu chapéu. 0 tigre pintado ao fundo, flagrado numa posição de ataque, tem as patas traseiras sobre uma bomba de gasolina, na qual está escrito "NAPALM EXTRA SUPERCARBURANT". Ao ser atingida por um dos aviões, Yvonne grita: "Socorro, socorro!". Logo após sua fala, há um corte abrupto da ação, e o instante, outrora suspenso com o estalar dos dedos de Guilhaume, é retomado.

Figura 3 Yvonne (Juliet Berto) encena uma vietnamita

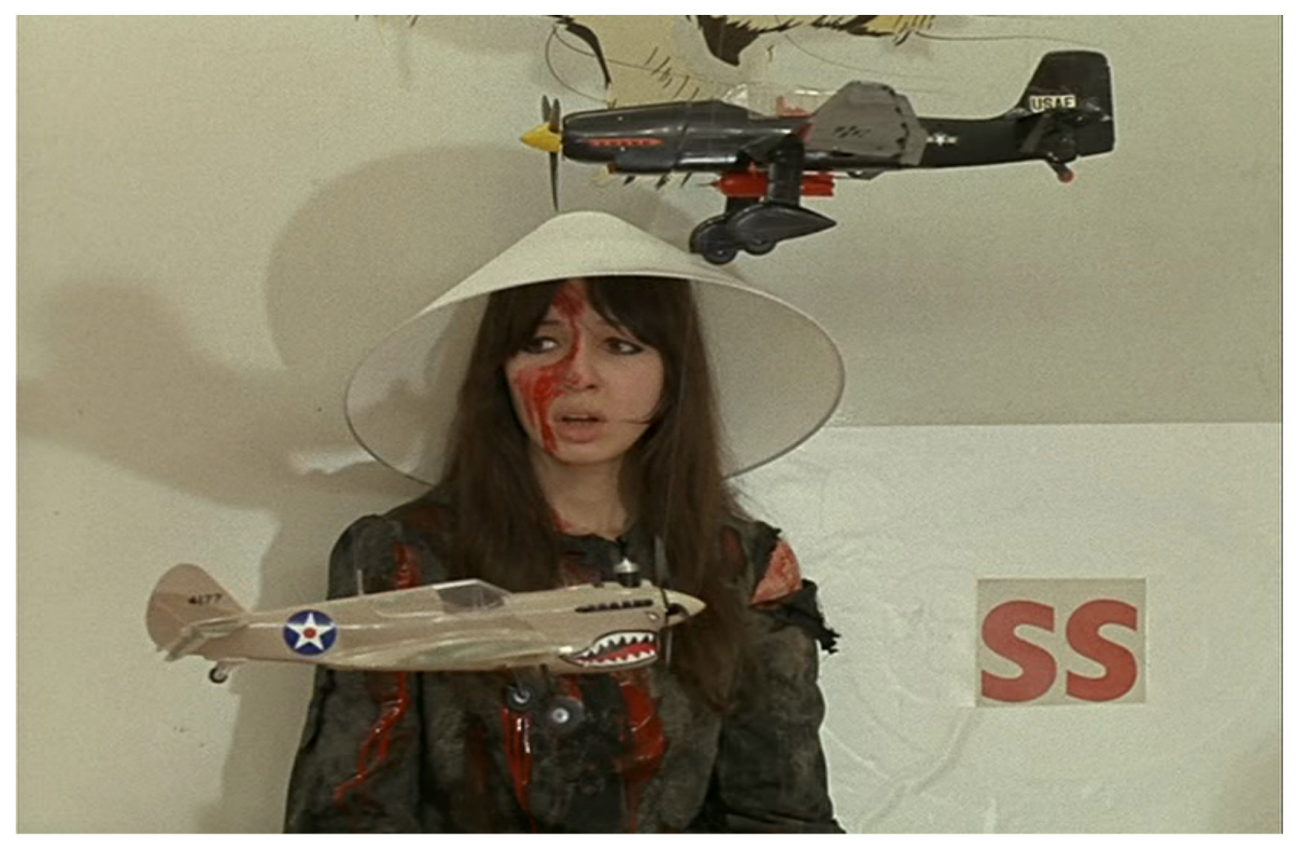

Fonte: La chinoise (1967). 
Os aviões que atacam Yvonne na cena são miniaturas de aeronaves utilizadas durante a Segunda Guerra Mundial. No canto inferior esquerdo (Figura 3), está uma miniatura de um modelo P-40, utilizado pelas forças norte-americanas durante o conflito. Na parte de baixo do aeroplano, podemos enxergar a nose art, ou arte de nariz de aeronaves. No canto superior direito, há um modelo de avião Stuka todo pintado de preto, que foi usado pelas forças alemãs.

A nose art, de acordo com Jeffrey L. Ethell (1992), não é uma inovação atual, pois desde os princípios da humanidade os seres humanos sentem a necessidade de personalizar suas armas. Dessa forma,

[...] a arte fez com que a arma parecesse ainda mais feroz. 0 rosto de um animal raivoso tem sido o favorito, principalmente com dentes afiados, prontos para devorar o inimigo. Quando o avião emergiu como uma arma de guerra, as tripulações começaram a transferir os rostos ferozes para suas máquinas (ETHELL, 1992, p. 6, tradução nossa).

A nose art, com o passar dos anos, foi largamente difundida, e, durante a Segunda Guerra Mundial, os pilotos dos aviões americanos foram cada vez mais aderindo a essa forma de expressão. Quando um grupo de pilotos americanos estacionados na China - portanto, antes da destruição da base naval de Pearl Harbor (dezembro de 1941) - fez uso da nose art em seus aeroplanos para combater os japoneses em território chinês, um oficial teve a ideia de pintar um tigre com dentes afiados. A partir de então, os esquadrões americanos passaram a ser denominados Tigres Voadores (Flying Tigers).

A exibição desses aeroplanos na película provavelmente obedece a um princípio maoísta, segundo o qual era bom ser atacado "pelo inimigo, na medida em que isso prova que traçamos uma clara linha de demarcação entre nós e ele" (ZEDONG, 2004, p. 26). Nesse sentido, a cena demarcaria os inimigos que precisavam ser combatidos: os americanos e os nazistas, ou melhor, os americanos seriam os nazistas daquele momento que precisavam ser combatidos.

Explicitadas as características da nose art e do maoísmo, cumpre retornar à sequência anteriormente referida. Guillaume está na tela após a encenação de Yvonne e olha, possivelmente, para ela, que está "fora" do enquadramento, pois ela foi a personagem que o havia interrogado sobre o papel do Vietnã na guerra. Guillaume olha para a câmera novamente (na verdade, para o espectador) e menciona: "antes de tudo, alguns fatos, pois a verdade está neles" (LA CHINOISE, 1967). Guillaume dirige a mão para a câmera e faz um novo estalo com os dedos.

Vê-se um plano americano do herói dos quadrinhos: Batman está em ação; ao seu lado, o Sargento Fury e, posteriormente, o Capitão América dividem espaço na tela. Essas imagens surgem na narrativa três vezes e são interpostas por um ruído na banda sonora, que sinaliza para uma metralhadora em ação. Ao serem justapostos imagens e som, sobretudo a imagem 
dos quadrinhos do Sargento Fury, tem-se a impressão de que a metralhadora dele é que propaga o estampido lancinante. Assim, a interposição das imagens produz o efeito de uma posição anti-imperialista por parte de Godard, na qual se torna desnecessária a visualização de uma ação que represente ou manifeste uma força excessiva sobre o outro ou que denote uma violência, já que os quadrinhos criam tal ação. De certa forma, Godard recupera aqui a tônica sobre a representação e a realidade que esteve presente em Câmera-olho ${ }^{19}$.

Nesse sentido, as imagens dos quadrinhos, destacadas de seu contexto de origem (a indústria de entretenimento americana), cumprem ou assumem outra condição: de crítica à intervenção americana na Guerra do Vietnã. Contudo, a fita apregoa uma resolução para o conflito com a vitória da FLN, sendo que a crítica à intervenção é uma temática periférica da obra.

Outro esquete reaparece na tela, não mais motivado pela ação de Guilhaume. Yvonne está com manchas vermelhas no rosto, sinalizando um combate. Ela posiciona-se atrás de uma pilha de livros vermelhos de Mao Zedong. Trata-se de uma casamata de livros vermelhos, que supostamente a protegerá (Figura 4). Ao fundo da cena, está uma cortina vermelha. Depois de mencionar por duas vezes que a FNL vencerá, volve-se para sua direita e segura um rádio, que, logo em seguida, transforma-se numa metralhadora. A onomatopeia que Yvonne pronuncia remete ao som de uma metralhadora, ao mesmo tempo que reporta ao quadro de Roy Lichtenstein, cujo nome, Takka (HONNEF, 2004), pronunciado de forma rápida, alude ao som da arma, que está presente na pintura referida. A onomatopeia tem por sentido demonstrar a guerra que se desenrola no Vietnã contra os americanos, sendo que estes são apresentados, na próxima imagem que surge na tela, sob a forma de um soldado que é esmagado por uma mão vermelha dentro de um círculo.

Tendo presente as considerações acima mencionadas, reiteramos que o papel da pop art na película e o uso do brinquedo de guerra facultou o acesso à obra mediante elementos que são comuns a determinados espectadores ou ao seu horizonte de expectativas, bem como possibilitou ao cineasta Jean-Luc Godard estabelecer o questionamento sobre o papel dos Estados Unidos no conflito do Vietnã.

\footnotetext{
19 - Câmera-olho é um curta dirigido e atuado por Jean-Luc Godard para o filme coletivo idealizado e coordenado por Chris Marker, Longe do Vietnã (1967), que contou com a colaboração de Alain Resnais, Agnès Varda, Claude Lelouch, Michèle Ray, Joris Ivens e William Klein. A película tinha como propósito afirmar o exercício da profissão em torno do cinema (técnicos, assistentes, diretores e amigos que trabalharam pelo filme) e externar a "solidariedade com o povo vietnamita em luta contra a agressão" (leia-se norte-americana), segundo depreende-se dos letreiros iniciais de Longe do Vietnã. De acordo com Esquenazi (2004, p. 231-233), a fita godardiana acabou por vincular-se à luta vietnamita contra os americanos e teve por finalidade criar zonas de resistência à opressão. Inclusive, determinadas cenas de A chinesa, algumas delas descartadas na versão final do filme, foram reaproveitadas em Câmera-olho. Longe do Vietnã e Câmera-olho estão disponíveis em: https://www.youtube.com/watch?v=SBe9CDDbvCo. Acesso em: jul. 2020.
} 
Figura 4 Modelo de cartaz do filme A chinesa publicado na França

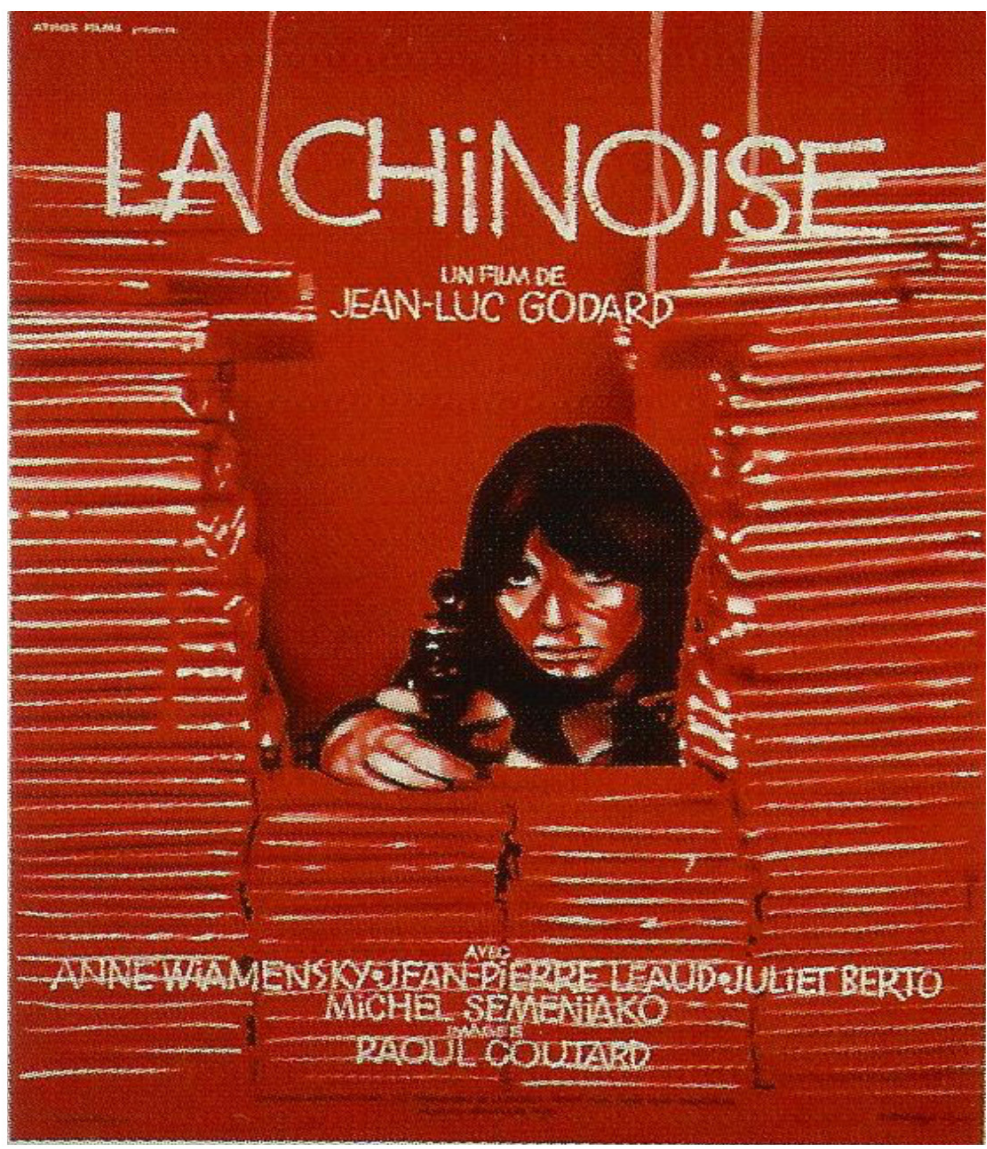

Fonte: Baecque (2010, p. 337).

\section{CONSIDERAÇÕES GERAIS: A PRESENÇA DE BERTOLD BRECHT}

Para terminar, é preciso estar ciente do fato de que a relação de Jean-Luc Godard com os autores com os quais toma contato obedece, nas palavras de Philipe Dubois (COUTINHO, 2013), a um princípio de bricolagem, categoria derivada de Claude Lévi-Strauss, segundo a qual o bricoleur é um tipo intermediário entre o engenheiro e o artista, que toma tudo o que acha pelo caminho e disso se apropria.

Se tudo é bom e passível de ser aproveitado, ocorre, por outro lado, que determinados autores desfrutam de maior apreço de Godard, sendo, inclusive, deveras lembrados ou incor- 
porados ao labor cinematográfico dele. Bertolt Brecht, por exemplo, detém um papel decisivo em películas do cineasta e em seu método de trabalho ${ }^{20}$.

Na fatura dos filmes de Jean-Luc Godard, são evidentes as interrupções nas sequências das narrativas cinematográficas para as encenações de esquetes com estreita vinculação com as suspensões dramáticas inscritas nas formulações brechtianas, cujos estribilhos, cartazes, canções e, postulamos, brinquedos, têm por objetivo "interromper a ação, e não ilustrá-la ou estimulá-la", segundo formulação de Walter Benjamin (1986, p. 80). Tais suspensões, como aquelas presentes em $A$ chinesa (que foram comentadas), são constituidas, nas fitas de Godard, por encenações ou por letreiros que adquirem, de acordo com Anatol Rosenfeld (1965, p. 158), ao tratar dos recursos cênicos e cênico-literários das peças do realizador Brecht, o estatuto de comentar a ação e esboçar o pano de fundo social.

Dessa forma, tais procedimentos cênicos se tornam, para concluir, na visão de Rosenfeld (1965, p. 158) "pequenas ilhas que criam redemoinhos de reflexão. [...] o espectador, graças a elas, não é engolfado na corrente do desenvolvimento da ação".

\title{
Film criticism and reception indexes in the film La chinoise (1967) by Jean-Luc Godard
}

\begin{abstract}
One of the main basic principles of aesthetic of reception ensures that a work is the result of the convergence of the text and its reception, and it cannot be apprehended except in its successive historical "embodiments" (assimilations) of readers (JAUSS, 1978, p. 246). According to this principle, the scope of a work takes into account the effect determined by the text and the reception handled by the recipient of the text. Thus, our goal was to observe what was the sense that the Godardian reception reached or acquired among Cinema Novo filmmakers and other film critics, in order to observe which aspects of La chinoise were relevant to them. Moreover, the film work of the French filmmaker brings together, in the same way, reception indexes (the toy) that allow or assist the "entrance" in the tape by the spectators, when forging certain clues or mechanisms that are common among them in some sequences of the tape.
\end{abstract}

Keywords: Reception. Cinema Novo. La chinoise. Jean-Luc Godard. Toy.

\section{REFERÊNCIAS}

AUTRAN, A. Alex Viany: crítico e historiador. São Paulo: Perspectiva; Rio de Janeiro: Petrobras, 2003.

20 - A presença de Bertolt Brecht no cinema, ou melhor, o emprego de técnicas do dramaturgo alemão derivadas originalmente do teatro e incorporadas ao fazer cinematográfico, foi sintetizada por Robert Stam (2011). Esse quadro expositivo nos permitiu alinhar e precisar os procedimentos teatrais de Brecht, dos quais, de maneira geral, as fitas de Jean-Luc Godard se imbuíram. 
BAECQUE, A. de. Godard: biographie. Paris: Grasset, 2010.

BARBOSA, H. M. Jean-Luc Godard. Rio de Janeiro: Record, 1968.

BAXANDALL, M. Padrões de intenção: a explicação histórica dos quadros. Tradução Vera Maria Pereira. São Paulo: Companhia das Letras, 2006.

BENJAMIN, W. A obra de arte na época da sua reprodutibilidade técnica. In: BENJAMIN, W. Magia técnica, arte e política: ensaios sobre literatura e história da cultura. 2. ed. São Paulo: Brasiliense, 1986. p. 164-196.

BENTES, I. (org.). Glauber Rocha: cartas ao mundo. São Paulo: Companhia das Letras, 1997.

BLOOM, H. A angústia da influência: uma teoria da poesia. Tradução Marcos Santarrita. 2. ed. Rio de Janeiro: Imago, 2002.

BOULLENOIS, C. A revolution culturelle chinoise sous le regard des français (1966-1971). Paris: L'Harmattan, 2013.

CAMÉRA-OEIL. Direção: Jean-Luc Godard. França: Chris Marker; Jean-Luc Godard, 1967. (15 min), color., $16 \mathrm{~mm}$. Disponivel em: https://www.youtube.com/watch?v=SBe9CDDbvCo. Acesso em: jul. 2020.

CARDOSO, M. O cinema tricontinental de Glauber Rocha: política, estética e revolução (19691974). 2007. Tese (Doutorado em História) - Universidade de São Paulo, São Paulo, 2007.

CHEVRIER, Y. Mao e a revolução chinesa. Tradução Mauro Lando e Isa Mara Lando. São Paulo: Ática, 1996.

COUTINHO, M. A. (org.). Godard, cinema, literatura (entrevistas). Belo Horizonte: Crisálida, 2013.

DIEGUES, C. Contracapa. In: BARBOSA, H. M. Jean-Luc Godard. Rio de Janeiro: Record, 1968. ESQUENAZI, J.-P. Godard et la société française des années 1960. Paris: Armand Colin, 2004. ETHELL, J. Shark's teeth nose art. Hong Kong: Motorbooks International, 1992.

FOLHA DE S. PAULO. São Paulo: Octávio Frias de Oliveira, p. 3, abr./maio 1968. Diário. Disponivel em: http://acervo.folha.uol.com.br/. Acesso em: jan. 2015.

FONSECA, R. Como era triste a chinesa de Godard. Rio de Janeiro: Record, 2011.

GODARD, J.-L. Godard par Godard: des années Mao aux années 80. Paris: Flammarion, 1991. GOMES, P. E. S. Tolice x La Chinoise. In: CALIL, C. A.; MACHADO, M. T. (org.). Paulo Emílio: um intelectual na linha de frente. Rio de Janeiro: Embrafilme; São Paulo: Brasiliense, 1986a. p. 248-249. 
GOMES, P. E. S. A chinesa. In: CALIL, C. A.; MACHADO, M. T. (org.). Paulo Emilio: um intelectual na linha de frente. Rio de Janeiro: Embrafilme; São Paulo: Brasiliense, 1986b. p. 254-255. GUBERN, R. Godard polemico. 2. ed. Barcelona: Tusquets Editor, 1974.

GUEVARA, E. C. Crear dos, tres... muchos Vietnam: mensaje a los pueblos del mundo a través de la Tricontinental. Cuba: Biblioteca de Textos Marxistas en Internet, 2003. Disponivel em: http://www.marxists.org/espanol/guevara/04_67.htm. Acesso em: 10 maio 2014.

HONNEF, K. Pop art. Tradução Constança Paiva Boléo Santana. Lisboa: Taschen, 2004.

JAUSS, H. R. Posface. In: JAUSS, H. R. Pour une esthétique de la réception. Paris: Editions Gallimard, 1978. p. 243-262.

JAUSS, H. R. A história da literatura como provocação literária. Tradução Teresa Cruz. 2. ed. Lisboa: Veja: Passagens, 2003.

JORNAL DO BRASIL. Rio de Janeiro: Tales Faria, abr./maio 1968. Diário. Disponivel em: https:// news.google.com/newspapers?nid=0qX8s2 k1IRwC\&dat=19680403\&tprintsec=frontpagecthl =pt-BR. Acesso em: 15 jan. 2015.

KOSELLECK, H. Futuro passado: contribuição à semântica dos tempos históricos. Tradução Wilma Patricia Maas et al. Rio de Janeiro: Contraponto: Editora PUC-RJ, 2006.

LA CHINOISE. Direção: Jean-Luc Godard. França: Silver Screen Collection, 1967. 1 DVD (96 $\mathrm{min})$, color.

LONGE do Vietnã. Direção: Joris Ivens, William Klein, Claude Lelouch, Agnès Varda, Jean-Luc Godard, Chris Marker e Alain Resnais. Paris: Ivens; Klein; Lelouch; Varda; Godard; Marker; Resnais, 1967. 1 DVD (115 min), color.

MAGALHÃES, M. Marighella: o guerrilheiro que incendiou o mundo. São Paulo: Companhia das Letras, 2012.

MARNIX, D. Ombres chinoises: regards de maoïtas français sur la Chine de Mao (1965-1976). Matériaux pour l'histoire de notre temps, n. 94, p. 16-32, juil./déc. 2009. Disponivel em: http://.cairn.info/revue-materiaux-pour-I-histoire-de-notre-temps-2009-2-page-16.htm. Acesso em: 20 nov. 2014.

O GLOBO. Matutina, geral, p. 7, 2 abr. 1968. Disponivel em: https://acervo.oglobo.globo.com/ consulta-ao-acervo/?navegacaoPorData=196019680402. Acesso em: 2 out. 2021.

PAIVA, M. R. A aventura de Glauber na guerrilha brasileira. MAIS!, São Paulo, p. 6-7, 5 maio 1996.

ROCHA, G. Você gosta de Jean-Luc Godard? Se não, está por fora. Livro de Cabeceira do Homem, Rio de Janeiro, ano 1, v. 3, p. 83-98, 1967. 
ROCHA, G. Revolução do cinema novo. Rio de Janeiro: Alhambra: Embrafilme, 1981.

ROSENFELD, A. O teatro épico. Rio de Janeiro: Ao Livro Técnico S.A., 1965.

SIMÕES, I. Roteiro da intolerância: a censura cinematográfica no Brasil. São Paulo: Editora Senac, 1999.

STAM, R. Introdução à teoria do cinema. 5. ed. Campinas: Papirus, 2011.

ZEDONG, M. O livro vermelho. Tradução Edições em Línguas Estrangeiras Pequim. São Paulo: Martin Claret, 2004. 